\title{
Intergenerational Justice for Children: Restructuring Adoption, Reproduction \& Child Welfare Policy
}

\section{Citation}

Elizabeth Bartholet, Intergenerational Justice for Children: Restructuring Adoption, Reproduction \& Child Welfare Policy, 8 Law \& Ethics of Hum. Rts. 103 (2014).

\section{Published Version}

http://www.degruyter.com/view/j/lehr.2014.8.issue-1/lehr-2014-0002/lehr-2014-0002.xml? format=INT

\section{Permanent link}

http://nrs.harvard.edu/urn-3:HUL.InstRepos:10777664

\section{Terms of Use}

This article was downloaded from Harvard University's DASH repository, and is made available under the terms and conditions applicable to Open Access Policy Articles, as set forth at http:// nrs.harvard.edu/urn-3:HUL.InstRepos:dash.current.terms-of-use\#OAP

\section{Share Your Story}

The Harvard community has made this article openly available.

Please share how this access benefits you. Submit a story.

\section{Accessibility}




\section{Elizabeth Bartholet*}

\section{Intergenerational Justice for Children: Restructuring Adoption, Reproduction and Child Welfare Policy}

Abstract: An intergenerational justice perspective requires that we look at the condition of the existing generation of children and those to be born in the future. Many millions of the existing generation of children are now in trouble and at high risk of never fulfilling their human potential. These children are in turn unlikely, if they live to produce children, to be capable of providing the nurturing parenting that the next generation will need.

The article's starting premises are that we should count child interests as of equivalent value to adult interests and that we do owe justice not just to the existing generation of children but to the next generations as well. Justice to the next generations means encouraging the creation of children who will have a good chance to enjoy the pleasures of life, children who will be born healthy and will be brought up by nurturing parents. Given these premises, there is much wrong with current reality and related policy.

We now encourage the reproduction of more children than we can care for, provide limited child welfare enabling poor parents to better care for their children, and discourage adoption both domestic and international. We should reverse these policies. We should change the pronatalist and anti-contraception policies that encourage the reproduction of children who won't likely be born healthy or receive nurturing care. We should provide child welfare so that poor parents who want to keep and raise their children can do so. We should encourage adoption, both domestic and international.

DOI 10.1515/lehr-2014-0002

*Corresponding author: Elizabeth Bartholet, Harvard Law School, Cambridge, MA, USA, E-mail: ebarthol@law.harvard.edu 


\section{Introduction}

This article grows out a conference on "Intergenerational Justice," a stimulating title that calls for thinking about basic principles of justice. ${ }^{1}$ My specific topic is justice for children and the questions I address are these. What if we took seriously the idea of providing intergenerational justice for children? What if we thought justice for children was as important as justice for adults? How differently would we then shape policy surrounding adoption, reproduction, and child welfare?

My starting premises are that we should count child interests as of equivalent value to adult interests and that we do owe justice not just to the existing generation of children but to the next generations as well. And for me, justice to the next generations means encouraging the creation of children who will have a good chance to enjoy the pleasures of life, children who will be born healthy and will be brought up by nurturing parents. ${ }^{2}$ Given these premises, there is much wrong with current reality and related policy.

I acknowledge that other forms of justice are also important. For example, justice to adults, and justice to the poor or redistributive justice, should also count. But my claim is that in today's world justice to children is regularly shortchanged.

A thought experiment may illuminate the issues. There are now some 8-12 million children growing up in institutions worldwide, ${ }^{3}$ rather than with the nurturing parents we know are essential to enable children to grow up healthy and happy, free from mental and physical disabilities, and able to live fulfilling lives. What if someone or some country were to propose mandatory sterilization of 8-12 million adults thus denying them any opportunity to become parents?

1 "Intergenerational Justice," The Eighth International Human Rights Researchers Workshop, College of Law \& Business, Ramat Gan, Israel, January 2013.

2 My argument is not based on any notion that any particular children have a right to be born. Nor do I find it relevant to consider whether born children who suffer health or parenting problems have a life worth living and thus have suffered no injustice by being born into less than ideal circumstances. The fact is that some number but not an infinite number of children will be born. Policy-makers have the right and responsibility to encourage the creation of children who will have a good chance to enjoy their lives.

3 Save the Children, Keeping Children out of Harmful Institutions: Why We Should be Investing in Family-Based Care (Nov. 2009), available at http://www.savethechildren.org. uk/resources/online-library/keeping-children-out-of-harmful-institutions-why-we-should-beinvesting-in-family-based-care (noting at least 8 million and likely much higher number). While there is no accurate count of institutionalized children available, many think the figure is in the $8-12$ million range. 
There would of course be universal outrage at this denial of what is seen as a fundamental adult right, the right to procreate. Where is the outrage over denying the 8-12 million institutionalized children the fundamental right to be parented? Where is the outrage over denying this right to the hundreds of millions of children growing up on the streets? Where is the outrage at the world's 150-million-plus orphan population, including its 18 million orphaned by both parents? ${ }^{4}$ Of those not institutionalized, most live in dire conditions of poverty, at high risk for an early death, and many live without anything resembling true parenting. ${ }^{5}$ Where is the outrage over the unparented?

Another thought experiment may help. The United States Congress decided recently that the violation of a single adult prisoner's rights in Russia were sufficiently important to enact a law known as the Magnitsky Bill imposing sanctions on some of those at fault. In retaliation, Russia shut down all international adoptions to the U.S. ${ }^{6}$ During each of the 2 years prior to this shutdown, Russia sent roughly 1,000 children into the U.S. ${ }^{7}$ In 2004 Russia sent almost 6,000. ${ }^{8}$ Russia imposed restrictions over the years 2004-2011 designed to deliberately reduce those numbers. Yet Russia has some 650,000 children denied real parenting, stuck in institutional or foster care. ${ }^{9}$ Limiting international adoption simply condemns children who could have found parents in adoption to live without parents. What if Russia had sterilized thousands of adults per year over this period of time? There would have been outrage and some form of action by the U.S. and the larger world community. But while many have decried Russia's international adoption shutdown, the general understanding is that Russia has

4 UNICEF, Childinfo, Orphan Estimates, available at http://www.childinfo.org/hiv_aids_orphanestimates.php (last visited Mar. 18, 2014). See also Linda J. Olsen, Live or Let Die: Could Intercountry Adoption Make the Difference? 22 Penn St. InT'L L. Rev. 483, 501 (2004).

5 See Christopher Balding, Framing the Need of International Child Adoption, at Pepperdine U. School of Law Conference on Intercountry Adoption, Orphan Rescue or Child Trafficking? (Feb. 8-9, 2013), available at http://law.pepperdine.edu/nootbaar/annual-conference/intercountryadoption/.

6 David M. Herszenhorn \& Andrew E. Kramer, Russian Adoption Ban Brings Uncertainty and Outrage, N. Y. Times, Dec. 29, 2012, at A9, col. 3. While some supporters of the shutdown argued that certain Russian children had been abused by their U.S. adoptive parents, it was obvious that it was the Magnitsky Bill that triggered the shutdown. Complaints about individual abuse cases had surfaced over the years with no such shutdown. See discussion infra section "Intergenerational Injustice in Action: Recent Illustrations of the Problem" for the frivolous nature of complaints that Russian children suffered in adoption in the U.S.

7 Bureau of Consular Affairs, U.S. Dept. of State, Intercountry Adoption 2010-2011, http://adoption.state.gov/about_us/statistics.php.

8 Id.

9 Herszenhorn \& Kramer, supra note 6. 
the sovereign right to hold onto its children regardless of whether it provides those children the parenting they need. There has been some pressure to free up the relatively small group of children already officially assigned to adoptive parents, but very little to address the needs of the many thousands per year denied homes by the cutbacks and the shutdown. Congress has passed no equivalent to the Magnitsky Bill sanctioning Russia for the denial of child human rights.

A final thought experiment involves UNICEF. UNICEF has over recent years been a major force driving down the numbers of international adoption worldwide. ${ }^{10}$ While UNICEF recognizes that institutions are seriously destructive for children and officially opposes keeping them in institutions, the net of UNICEF's policy is to condemn to institutional care tens of thousands of children who used to get adoptive homes abroad. The in-country adoptions that UNICEF promotes in theory are for the most part simply unavailable. The other in-country placement options like paid foster care, group homes, and sibling-headed households are in short supply and, in any event, not nearly as good for children as a general matter as adoption, whether domestic or international. ${ }^{11}$ The U.S. Congress provides UNICEF an annual grant of $\$ 132$ million in direct support, with additional millions for country-specific programs. ${ }^{12}$ If UNICEF were known to promote the mandatory sterilization of tens of thousands of adults on an annual basis, there would be outrage. It is hard to imagine that Congress would continue to fund UNICEF annually without setting any conditions on use of the funds so as to discourage or eliminate the sterilization program. But to date Congress has set no conditions designed to encourage UNICEF to change its policy on international adoption.

An intergenerational justice perspective requires that we look at the condition of the existing generation of children and those to be born in the future, and consider policy reform that might better serve all those children. Many millions

10 See, e.g., Elizabeth Bartholet, International Adoption: Thoughts on the Human Rights Issues, 13 Buff. Hum. Rts. L. Rev. 151, 152, 153-57 (2007).

11 Elizabeth Bartholet, International Adoption: The Human Rights Position, 1 Global Policy 91, 92-93 (2010); Bartholet, International Adoption: Thoughts on the Human Rights Issues, supra note 10, at 179-81; Elizabeth Bartholet, The International Adoption Cliff: Do Child Human Rights Matter?, in The Intercountry Adoption Debate: Dialogues Across Disciplines (May 29, 2013 version) (Cambridge Scholars Publishing, forthcoming 2014), http://www.law.harvard.edu/faculty/ bartholet/IA\%20Adoption\%20Cliff\%205-30-13.pdf.

12 Senator Mary Landrieu questioning UNICEF representative Susan Bissell at Senate Appropriations Subcommittee on State, Foreign Operations, and Related Programs, U.S. Senate Committee on Appropriations, Review of U.S. Foreign Assistance for Children in Adversity, May 21, 2013. 
of the existing generation of children are now in trouble and at high risk of never fulfilling their human potential. These children are in turn unlikely, if they live to produce children, to be capable of providing the nurturing parenting that the next generation will need.

We now encourage the reproduction of more children than we can care for, provide limited child welfare enabling poor parents to better care for their children, and discourage adoption both domestic and international. We should reverse these policies. We should change the pronatalist and anti-contraception policies that encourage the reproduction of children who won't likely be born healthy or receive nurturing care. We should provide child welfare so that poor parents who want to keep and raise their children can do so. We should encourage adoption, both domestic and international.

The broad restructuring of policy that would be required to provide anything we might call intergenerational justice for children would not be easy. But existing policy is perverse - not only is it unfair to children but it is unfair to adults as well. Children are as they say our future. Societies that damage their children will have to live with those children when they grow up. And children who grow up unparented are at high risk for crime, substance abuse, unemployment, poverty, and other problems that will make them a drag on the larger society. We should be able to reverse the perverse.

\section{The Problem}

\section{The Children}

\section{This Generation}

Worldwide, and especially in developing countries, the situation for untold millions of children is truly desperate. There are appalling numbers of early preventable deaths. ${ }^{13}$ There are appalling numbers of biological orphans, both single and double, with the numbers dramatically increased in recent decades due to AIDS. AIDS orphan estimates indicate that as of 2010 some 18.4 million children had lost one or both parents to AIDS. ${ }^{14}$

13 Kay Warren et al., Development in America's Interest: Engaging the American Public on Development Issues (Mar. 15, 2012) (unpublished manuscript) (on file with author).

14 Jini Roby \& Stacey Shaw, The African Orphan Crisis and International Adoption, 51 Soc. WoRK 199 (2006). 
In addition to the 153 million biological orphans, single and double, there are also many millions of "social orphans" - unparented children who, regardless of whether they have a biological parent, are not being nurtured by that parent, and won't be in the foreseeable future. This includes the 8-12 million children who are living, or dying, in institutions. ${ }^{15}$ Although most of them are said to have a biological parent, few have a significant current social relationship with their parents, and few will ever be released from the institution to be reunited with their parents. The situation has been getting worse, with the number of institutions increasing. ${ }^{16}$

Appalling numbers of children live in miserable conditions, either on the streets or at home in desperate poverty. One billion children are undernourished. ${ }^{17}$ "Half of our world - three billion people - lives on less than two dollars a day. Over one billion live on less than one dollar a day. One-sixth of the world's population lives in slums, in grinding, dehumanizing poverty." ${ }^{18}$ In lower- and middle-income countries, an estimated 200 million children under 5 years of age - more than $30 \%$ of the world's children - are defined as failing to reach their developmental potential, limiting their future ability for a meaningful life. ${ }^{19}$

Roby and Shaw describe in a recent article some of the suffering common in Africa:

The suffering of African orphans is relentless and huge in magnitude. Orphans are more deprived than their national peers of education, socialization, and nutrition. They face isolation, prejudice, crime, abuse, neglect, child labor, prostitution, exploitation, and HIV infection. Psychological effects include depression, guilt, fear, and possible longterm mental health problems. Orphans living in child-headed households are even more at risk.

They go on to describe the breakdown of the traditional system in which kin took in their relatives' children, and the problems posed for children by much of such kinship care as still exists:

15 Save the Children, supra note 3.

16 John Williamson \& Aaron Greenberg, Families, Not Orphanages (Sept. 2010), at 3, available at http://www.crin.org/docs/Families\%20Not\%200rphanages.pdf.

17 Phillip Sharp, 2007 figures for undernourished population, with the world population slated to go up over the next decades, exacerbating the problem. New Biology and Convergence of Life Sciences and Engineering, Lecture at Harvard University, Science and Democracy Lecture Series, Dec. 11, 2012.

18 Warren et al., supra note 13.

19 Sally Grantham-McGregor et al., Developmental Potential in the First 5 Years for Children in Developing Countries, 369 THE LANCET 60 (2007), available at http://www.who.int/maternal_child_ adolescent/documents/pdfs/lancet_child_dev_series_paper1.pdf?ua=1. 
With the added strains, families are less willing or able to take orphans, and some even take advantage of them. In some cultures, unequal treatment of kin children is tolerated because of traditional lines of inheritance and socially accepted family roles. UNICEF in Kenya found that some orphans were treated poorly, abused, forced to work, and discriminated against.

Roby and Shaw talk of how countries feel forced to warehouse children in grossly inadequate, makeshift institutions. They describe how In Kenya, where 650,000 children have been orphaned by AIDS, hundreds of orphans were rounded up from the streets and put into "social halls," underground spaces in which children could be fed and housed overnight. ${ }^{20}$

\section{The Next Generation}

Unless major policy changes are instituted these problems will presumably continue for generations to come. And even if some progress is made in addressing world poverty, and building social welfare programs, the unparented children of this generation will not be in position to nurture the next generation appropriately.

Reproductive technology policy adds its own problems to the mix. As discussed below, it encourages the creation of new children at the expense of caring for those who exist. And it produces many children at high risk for serious disabilities.

\section{The Policy Governing Adoption, Reproduction and Child Welfare}

Intergenerational justice would demand that we take better care of existing children and that we create children with good prospects for healthy, happy lives. Current policy pushes in just the wrong directions. Worldwide government policy ignores the needs of existing children and encourages the creation of children regardless of the chances they will be born healthy and will receive good care. It drives potential parents away from the unparented

20 Roby \& Shaw, supra note 14, at 200-01 (citations omitted from quotations). For further documentation of the intolerable conditions suffered by an increasing number of orphans and institutionalized children worldwide see Balding presentation, supra note 5, and S. J. Chapman, Adopt, A New Way of Thinking (unpublished manuscript), available at http://philpapers.org/rec/ CHAAAN-2 (last visited Mar. 18, 2014). 
children who exist and need homes, encouraging instead the creation of new children.

\section{Limited Child Welfare to Support Poor Families and Existing Children}

Given the conditions of poverty and related chaos characterizing so much of the world, extensive child welfare programs are needed for many families in order to give them a chance to care adequately for their children. But for many of the same reasons poverty and chaos exist in these countries, such programs are sorely lacking. As a result many birth parents are forced either to bring up their children in desperately inadequate circumstances or to abandon their children to the streets or to institutions.

Birth mothers in countries of origin live under oppressive economic, social, and political conditions .... [M]ost birth mothers [in the Marshall Islands] were simply too poor to raise another child, especially as they had three or four other children to support. Similarly, most Latin American children in state institutional care are not the first children of teenage mothers, but the third or fourth children of very poor mothers.... In most cases birth mothers have no social support. ${ }^{21}$

\section{Reproduction Policy Encourages Creation of New At-Risk Children at the Expense of Caring for Existing Children}

Reproduction policy worldwide does little to help poor people who cannot afford to raise children avoid childbearing through contraception and/or abortion. U.S. policy in recent decades, together with religious advocacy by the Catholic Church, have severely curtailed access to family planning in the developing world. Many poor women throughout the world give birth to children they know they cannot raise because of the circumstances of their lives, and would relish the chance to choose not to endure pregnancy, childbirth, and the experience of abandoning or surrendering their child. They would relish the chance to do a better job caring for children they already have by avoiding the burdens of additional children. Too few now have that choice.

21 Riitta Högbacka, Maternal Thinking in the context of Stratified Reproduction: Perspectives of Birth Mothers from South Africa, in Intercountry Adoption: Policies, Practices, And Outcomes 143, 145 (Judith Gibbons \& Karen Rotabi eds., 2012). 
At the same time reproduction policy worldwide encourages privileged people to create new children rather than consider adopting existing unparented children. Most countries give fertile parents a powerfully protected right to procreate. Countries often surround this right with powerful socializing that privileges biological parenting over adoptive parenting. Privileged countries often provide economic incentives to procreate, ensuring that costs of childbirth, including the costs of even very expensive and repeated infertility treatments, are covered through national health care or required health insurance. ${ }^{22}$ In the U.S., there are almost no restrictions on who can use reproductive technology, and almost no rules limiting the ability to buy sperm, eggs, and pregnancy and childbirth services through what we call surrogacy. There are also almost no restrictions designed to protect the health of those to be born. And while some states have such restrictions, consumers can avoid the restrictions simply by seeking services in other states within the U.S. As a result there are in the U.S. a high percentage of high-risk children born through use of assisted reproductive technologies (ARTs), mainly because of the multiple gestations resulting from our IVF practice, leading to a huge increase in the rate of twins, triplets, quadruplets, and other multiple births. ${ }^{23}$

Many other countries with advanced reproductive technologies have significant regulation restricting use within their borders. Generally, this kind of restrictive regulation is designed to protect the vulnerable, including children. For example, some countries prohibit certain people from using ARTs based on concern regarding their fitness to parent. Some prohibit commercialization - e.g. the selling of eggs, sperm, pregnancy and childbearing services, and parental rights - based on concern that it cheapens life for all including the children born. Some prohibit anonymous donor/ vendors, based on concern for children's need to know their birth heritage.

22 See for discussion of these issues in the U.S., and the problematic contrast with adoption regulatory policy, in Elizabeth Bartholet, Family Bonds: Adoption, Infertility, And The New World Of Child Production (Beacon Press, 1999) originally published in 1993 by Family Bonds: Adoption \& The Politics Of Parenting (Houghton Mifflin, 1993).

23 See Committee Opinion No. 324: Perinatal Risks Associated with Assisted Reproductive Technology, Am. Coll. Obstetricians \& Gynecologists (2005, reaffirmed 2008), available at http://www.acog.org/ /media/Committee\%200pinions/Committee\%20on\%20Obstetric\%20Practice/co324.pdf?dmc=1\&ts \%C2\%B120121019T1144155702; See also Michele Goodwin, Precarious Moorings: Tying Fetal Drug Law Policy to Social Profiling, 42 Rutgers L.J. 659, 680-82 (2011) (discussing some of the negative consequences of ART). Single embryo transfer has been found to have "measurable positive health impacts for pregnant women and the children to whom they give birth." Hazel Biggs \& Caroline Jones, Tourism: A Matter of Life and Death in the United Kingdom, in The Globalization of Health Care: Legal And Ethical Issues 164, 174 (Glenn Cohen ed., 2013). 
Some prohibit the implantation of more than one embryo in IVF, based on concern that multiple births produce children at high risk for disability and impose health risks on the gestating mother. ${ }^{24}$

However, those with adequate means can generally escape such restrictions by simply traveling to the U.S. or other countries that are similarly permissive. Reproductive tourism, part of the larger medical tourism phenomenon, is a burgeoning industry. ${ }^{25}$ All signs indicate that it will continue to expand, in part because of the massive amounts of money involved for the countries providing services and for private parties. ${ }^{26}$ These financial incentives will counter any attempt to expand restrictive regulation.

By contrast, the policy shaping adoption drives privileged people who are in a good position to offer homes to the unparented away from this choice. There is no right to adoption even in the rights-oriented U.S. Adoptive parenting is stigmatized in most countries as inferior to biological parenting. Most adopters pay the costs of adoption - subsidies in the U.S. are available only for special needs adoption, and while tax credits are available for some of the costs of adoption they rarely come close to meeting the costs of adoption. Restrictive regulation governing adoption screens out many prospective parents who have no trouble accessing reproductive technology in the U.S. And restrictive regulation ensures that many of the children available for adoption have been kept in destructive limbo for years, in institutional or foster care, prior to being freed

24 Glenn Cohen, Circumvention Tourism, 97 CoRnell L. Rev. 1309, 1323 (2012) (description of kinds of restrictions imposed in different countries); Richard Storrow, The Proportionality Problem in Cross-Border Reproductive Care, in The Globalization of Health Care, supra note 23, at 125, 127 (many restrictions in Europe and Australia, with different countries' laws amounting to "a dizzying patchwork"), and at 129 (describing some countries' specific restrictions); Kimberly Mutcherson, Defending Access to Cross-Border Fertility Care in the United States, in The Globalization of Health Care, supra note 23, at 148, 151-52.

25 See generally Raywat Deonandan, An Introduction to the Ethical Dimensions of Reproductive Medical Tourism, 4 Travelling Well: Essays in Medical Tourism: Transdisciplinary Studies in Population Health Series 151, 152-53 (2013), available at http://www.iph.uottawa.ca/eng/transdis/files/Volume\%204\%20Issue\%201.pdf (discussing rapid expansion of reproductive tourism); Cohen, Circumvention Tourism, supra note 24, at 1311.

26 Deonandan, supra note 25, at 173 (reproductive tourism growing rapidly and shows no signs of disappearing); Cohen, supra note 24 , at 1311 (medical tourism a rapidly growing multibilliondollar industry involving thousands of patients from the United States alone); Ronald Labonte, Overview: Medical Tourism Today: What, Who, Why and Where?, Traveluing Well, supra note 25, at 6, 8 (medical tourism a burgeoning new entrepreneurial sector with annual global value of over $\$ 100$ billion in 2012, and perhaps 5-6 million medical tourists annually); Mutcherson, supra note 24, at 150 (most agree that reproductive tourism will continue to increase). 
for adoption, thus driving away prospective parents who want to raise a healthy child. ${ }^{27}$

The result is a formidably stacked deck pushing prospective parents to create new children rather than give homes to those who exist and are in need. I discuss this stacked deck and some of the solutions at much greater length in my book Family Bonds. ${ }^{28}$

\section{Severe Restrictions on International Adoption Prevent Unparented Children from Being Placed with the Parents They Need}

International adoption provides one way to serve the needs of at least some tens of thousands annually of the world's unparented children. The world divides unfortunately between relatively well-off countries with many adults looking to parent and desperately poor countries with many unparented children and few in-country prospective adopters. Restrictions have always existed making it difficult to place the children in need with those eager to parent. But for six decades, from the end of World War II until 2004, the numbers of international adoptions steadily rose, as various countries moved to allow and enable such adoption. However, since 2004 the world has reversed direction. The numbers of international adoptions have dropped precipitously. From its worldwide peak of 45,000 annually the numbers have dropped by more than half. ${ }^{29}$ The numbers for children coming into the U.S. dropped by two-thirds as of 2013, as the following chart shows.

Many countries that allow international adoption have imposed restrictions that harm the children lucky enough to be placed and that accordingly limit the appeal of adoption for prospective parents, driving them to seek reproductive options. Thus many countries require that in-country options be explored before international adoption can be considered, resulting in long delays in placement. As a result, while in earlier times children were often placed internationally as infants, this almost never occurs today. ${ }^{30}$ Yet child welfare experts know that

27 See generally BaRtholet, FAmily Bonds, supra note 22.

28 Id.

29 Peter Selman, Key Tables for Intercountry Adoption: Receiving States 2003-2012; States of Origin 2003-2012, available on request from the author at pfelsman@yahoo.co.uk or on the Hague website at http://www.hcch.net/upload/selmanstats33.pdf. Table 1 (falling from over 45,000 in 2004 to 19,336 in 2012). See also email from Selman to Bartholet, Apr. 13, 2014 (on file with the author).

30 Peter Selman, Global Trends in Adoption, slide 10, supra note 5 (showing small percentage adopted under 1 year of age as compared to over 5 years of age). 


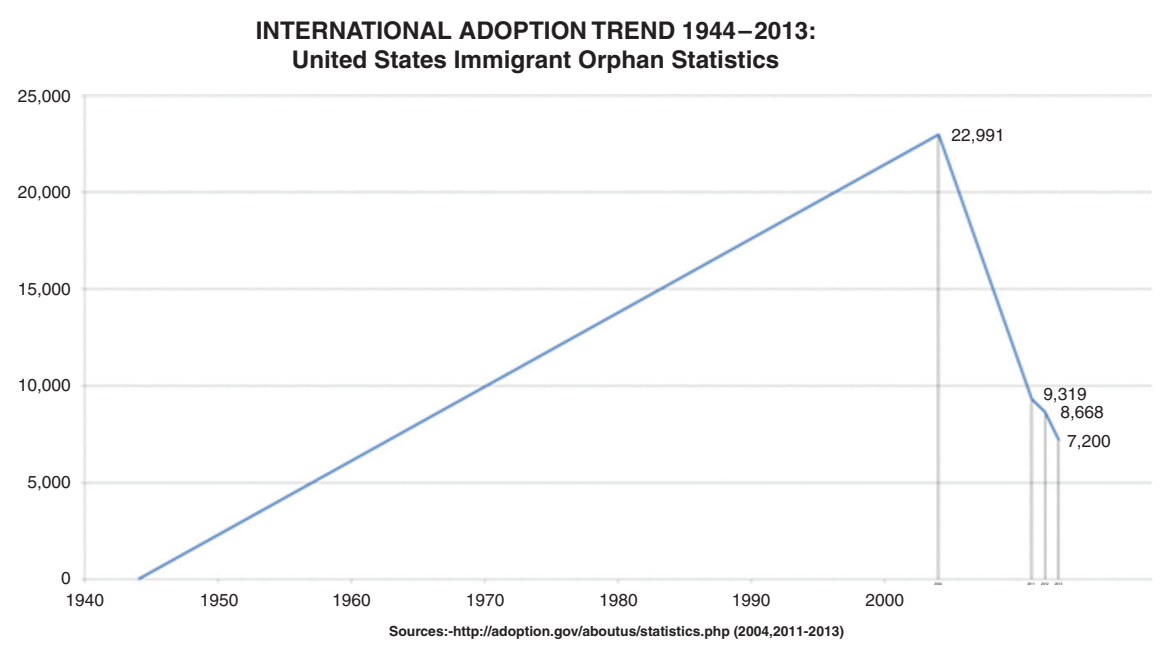

keeping infants in institutional care for more than a few months puts them at enormous risk for lifelong damage, even if they are ultimately adopted, the risk increasing proportionately with the length of stay. ${ }^{31}$

The reduction in numbers of international adoptions is the result of deliberate policy designed to drive the numbers down. There has been no reduction in the needs of unparented children, but only an increase. And while international adoption has been made more difficult and expensive for prospective adopters, and the children placed often have severe disabilities and extreme needs, there is no dearth of eager adoptive parents. Some sense of the potential pool of adoptive parents comes from infertility statistics. Estimates indicate a worldwide $9 \%$ prevalence for current infertility and 16\% prevalence for lifetime infertility in couples in fertile age groups. ${ }^{32}$ Almost one million people in the $\mathrm{U}$. S. alone are seeking to adopt at any given time. ${ }^{33}$ The major reason they give for not adopting is their inability to find an available child. ${ }^{34}$ And the fertile

31 Elizabeth Bartholet, International Adoption: The Child's Story, 24 Ga. State U. L. Rev. 333, 348, \& n.28 (2007). For a recent helpful summary of the significance of the Budapest Early Intervention Project's findings on the harm of institutionalization, discussed in that footnote 28, see Zeanah Nelson et al., Anguish of the Abandoned Child, 308 (4) Scr. Am. 62 (Apr. 2013).

32 Mutcherson, supra note 24, at 148, 149.

33 J. Jones, Adoption Experiences of Women and Men and Demand for Children to Adopt by Women 18-44 Years of Age in the United States, 2002, Series 23, No. 7, August 2008 (data from the National Survey of Family Growth), available at http://www.cdc.gov/nchs/data/series/sr_23/ sr23_027.pdf.

34 Id. 
population adds to the pool, as many are interested in adoption for reasons other than inability to have biological children.

An economist called Christopher Balding has been compiling striking statistics that help illustrate some of the issues. He notes that there are $\sim 750,000$ women actively seeking to adopt children in the U.S. at any given moment and that the ratio of dual parent orphans in sub-Saharan Africa to the annual number of international adoptions into the U.S. is 910 to 1 . He documents the high death rates suffered by single and double orphans and asks: "Why are we letting these kids die when there are families that want to adopt and save them from near certain death?"35

The deliberate policy-makers responsible include countries of origin, receiving countries, ${ }^{36}$ and, ironically, organizations that purport to represent and protect children. Countries of origin often assert their right to hold onto their children regardless of any ability to care for the children. Receiving countries often have little regard for the rights of children in other countries, but a good deal of regard for protecting their own government against criticism. They see little to gain and much to lose if they appear to pursue children for adoption against any opposition.

The child rights organizations like UNICEF, Save the Children, and the U.N. Committee on the Rights of the Child play a major role in restricting and shutting down international adoption. ${ }^{37}$ They regularly promote virtually all in-country options for children over international adoption. While UNICEF says that it is against institutionalization, its policies effectively prefer institutionalization over international adoption because it advocates preferences for in-country options that don't exist now and won't for the foreseeable future, leaving children in institutions with no viable current solution. So, for example, UNICEF advocates the creation of child welfare policies enabling all poor people to keep and raise the children they produce, obviously an ideal solution but one which won't soon exist in this world.

These child rights organizations regularly promote in-country solutions that won't work nearly as well for children as international adoption, such as paid foster care, sibling-headed homes, and group homes. ${ }^{38}$

35 Balding, supra note 5.

36 Many countries function as both countries of origin, or sending countries, and receiving countries, but they generally function primarily as one or the other.

37 See generally Bartholet, International Adoption, supra note 11, at 154-57; Bartholet, International Adoption: The Human Rights Position, supra note 12, at 92-93.

38 See, e.g., Williamson \& Greenberg, supra note 16; Roby \& Shaw, supra note 14 (documenting how bad in-country options like foster and kinship care often are for children); Elizabeth Bartholet \& David Smolin, The Debate, in InTERCOUnTRY ADOPTIOn, supra note 21, at 233, 235-36. 
These organizations promote in-country adoption over international and advocate for holding periods delaying the possibility of placing children internationally so that efforts to find in-country adoptive homes can be pursued. But in-country adoption will not be an option for many unparented children in any near future. Few of the countries with large numbers of unparented children have any significant domestic adoption tradition. Biases in favor of blood-linked parenting and racial and ethnic biases against the children likely to be most in need of parenting limit the possibilities for developing in-country adoption. ${ }^{39}$ In any event, as I have discussed at length elsewhere, there is no evidence that in-country adoption would work better for children than international, and there is extensive evidence that delaying adoption for the purpose of finding in-country families hurts children. ${ }^{40}$ Age at the time of placement, along with the damage done by institutional care prior to placement, regularly shows up in the social science as the prime indicators of how well or badly adopted children will do..$^{41}$

Many assume that since these organizations purport to stand for children's rights and interests, they must be doing so. But there's no reason to defer to these organizations if they cannot produce reasons for their policies that make sense. And there's reason to be suspicious given the emphasis they place on sovereign state rights to control their children, and the related deference they

39 Roby and Shaw, supra note 14, discuss the limited possibilities for increasing in-country adoption in Africa:

[A]doption by nonkin has never been widely practiced in Africa because of strong cultural barriers. In some African cultures the adoption of a child is believed to introduce alien spirits into the family, and in-country adoption is most likely not going to provide a significant solution to the orphan crisis... We have observed cultural beliefs against adoption in several African countries.

40 See generally Bartholet, International Adoption, supra note 10, at 179-81; Bartholet \& Smolin, Debate, supra note 38, at 236-37.

41 A recent meta-analysis of international adoption research confirms these conclusions. See Femmie Juffer \& Marinus van IJzendoorn, Families with Intercountry Adopted Children: Talking About Adoption and Birth Culture, in InTERCountry Adoption, supra note 21, at 175, 183-84. It summarizes and analyzes existing evidence-based adoption research, concluding that adoption serves to enable children to recover from prior damage done by maltreatment and institutionalization, finding "impressive and massive catch-up after adoptive placement in all developmental domains, including physical growth, attachment, cognitive development, behavior problems, and self-esteem." Adopted children develop in a more optimal way than those left in institutions, with the age of placement key in determining how optimal development will be. The study also concludes: "Internationally adopted children are not at higher risk of maladjusted development compared to domestic adoptees, and for behavior problems they are even at lower risk" (emphasis added E.B.). 
pay to international law principles giving sovereign states the right to hold onto their children, denying them international adoptive homes, regardless of their ability to care for children or to free them from the horrors of institutional life. ${ }^{42}$ There is also reason to be suspicious of organizations whose long-term focus on certain in-country programs provides its own incentive to reject out-of-country solutions and organizations whose power and funding have traditionally been connected to in-country programs.

India has moved in recent decades to cut back on international adoption while increasing domestic adoption. The one study that has apparently been done actually testing the assumption underlying the preference for even in-country adoption involves India and compares how children do when placed domestically in India versus when placed internationally in the U.S. and Norway. Contrary to the assumption that child rights organizations use to promote their policies, this study found that the children placed internationally were doing significantly better than those placed within India. ${ }^{43}$

\section{Wrong Ideas About Rights}

Wrong ideas about rights help motivate and justify current policy. Adult individual and group rights trump child rights, despite all the talk about deferring to child best interests in matters affecting children. Adult rights to procreate and to hold onto the children of procreation drive the current system at the expense of children's rights to receive nurturing parenting. They help explain why we encourage adults to create new children rather care for those who exist. They help explain why many countries encourage the production of children through reproductive technologies with little regard for the welfare of the children to be born. ${ }^{44}$ Procreation is seen as a near-absolute right throughout most of the

42 See text infra note 48.

43 Suzanne Brown \& Victor Groza, Strengths and Liabilities of Domestic and Intercountry Adoption from India (2012) (unpublished paper) (on file with author). The study controlled for age of adoptive child at placement and at time of study, and other factors. Describing itself as the first published examining the evidence related to the subsidiarity principle, it found no evidence supporting the principle, noting that the international adoptees functioned "significantly better behaviorally" than the in-country adoptees (id. at 14). See also final quote in note 41 supra.

44 See discussion above about U.S. failure to screen for parental fitness and failure to protect against the birth of children at high risk for serious lifelong disabilities. See also Pamela LauferUkeles, The Lost Children: When Pronatalism Is Not Pro-Children, 8 (2) L. Eтнісs Hum. RTs. (forthcoming, 2014) (discussing the pronatalist policy in Israel that encourages the use of ARTs to produce children who will suffer various social disadvantages). 
world, including even in poor countries where procreation regularly results in the birth of children who cannot be nurtured. ${ }^{45}$

By contrast, children are not seen as having any equally important right to be brought up by nurturing parents, even though without such parents they are at risk of losing the chance to grow up capable of enjoying the pleasures of life.

I am not suggesting that we severely restrict the right to procreate or try to force unwilling adults to parent existing children in need. I am suggesting that we restack the economic and regulatory deck so as to encourage more adults to parent these existing children and discourage adults from procreating irresponsibly by either creating children at risk for physical or other problems or children for whom the parents will not be able to provide.

We could limit the subsidies provided for procreation both in its natural and in its technologically assisted form. These subsidies include, for example, national health care coverage in many countries for assisted reproduction and mandated insurance coverage for such reproduction in about a dozen states in the U.S. We could expand the kind of regulation that protects the health of the children born from IVF, limiting for example the number of embryos transferred so as to prevent multiple gestation.

We could ease the regulations surrounding adoption to encourage more prospective parents to give homes to children in need. We of course need to retain the adoption regulation providing essential protections to birth parents against coercive and fraudulent removal of children and protections ensuring children placement with good parents. But much current adoption regulation cannot be so justified - much simply stands in the way of children getting the nurturing homes they need. ${ }^{46}$

We could limit the free market in the world of reproduction, forbidding the use of money to induce birth and genetic parents to surrender their children and parental rights. The no-baby-buying rule is sacrosanct in the adoption area paying birth mothers to surrender their children is prohibited everywhere. Money drives the world of ART - if the rules prohibited paying for sperm, eggs, gestational services, and babies, in that world the practices would dry up almost entirely. Many would be outraged at restricting adult procreative rights by banning payment in this way. But the no-baby-buying rule in adoption

45 See Mulea Margaret Munalula, Rethinking the Right to Procreate: An African Imperative, 13 THEORETICAL InQ. L. 303 (2012) (describing the powerful right to procreate in Zambia, despite its overpopulation problems, and arguing that the right to procreate should be limited, balanced against the survival rights of the procreated children and/or third parties in need).

46 See generally Family Bonds, supra note 22; Elizabeth Bartholet, Nobody's Children: Abuse and Neglect, Foster Drift, and the Adoption Alternative ch. 3 (1999). 
is based on the idea that adults and children are better off if the children stay with their genetic and birth parents, if they retain what is seen as their birthright heritage. If these values are important then the same no-money rules should govern in the reproductive area. It's true that ART often produces children who will be cut off from only one genetic parent or one gestational surrogate birthing parent. But it's also true that ART often produces children cut off from both genetic parents and from the birthing parent, children to be raised, like traditional adoptees, by social parents with no genetic or biological connection. And in any event, our family law and adoption law treats the connection to even a single biological parent as a significant connection, not one to be severed without strong justification. Why should the adult's desire to become a parent be valued in this ART area over the child's right to grow up with its genetic and birthing parents? Why deliberately encourage, through allowing the free market, the creation of increasing numbers of children designed to be cast off from one or more biological forbears? ${ }^{47}$ Most countries with developed reproductive technologies restrict or totally prohibit the commercialization of reproduction, seeing many problems for children and the larger society in the sale of eggs, sperm, and surrogacy services. The U.S. is almost alone among developed countries in its affirmative embrace of such commercialization.

The adult rights orientation helps explain the restrictive regulation and policy surrounding adoption. We need some restrictive regulation of course, as noted above. But existing policies put too much of a premium on adult rights to hold on to children regardless of any ability to care for them. For example, institutions throughout the world are filled with children who are not free for adoption because they have one or more live birth parents, even though the parents are unable to care for them. UNICEF and many others argue that if parents are innocent of wrongdoing, if they have for example given up their child because of poverty and inability to provide care, then the children should not be freed for adoption. They argue for focusing all efforts on reuniting such children with their birth parents, without regard to the fact that realistically we know that many of these children will in fact never be successfully reunited, but will instead continue to languish in institutions. Similarly, many policy-makers believe that countries should be seen as having an absolute right to hold onto

47 Again, I reject the arguments some make that these children are better off alive than if not created. See note 2 supra. Society has the duty to limit the number of children born to a reasonable number that this earth is capable of supporting and to maximize the likelihood that those born will live happy, healthy, fulfilling lives. If society determines that generally children are best off growing up with their biological forbears, it should encourage the birth of children who will have this opportunity. 
their children, denying international adoption altogether, regardless of whether the country can provide parenting care. International law in the form of the Convention on the Rights of the Child and the Hague Convention on International Adoption takes this position. ${ }^{48}$ If we valued the child's right to grow up with a nurturing parent equally with adult rights to procreate and parent, it seems obvious that we would not tolerate policies like these that have the effect of locking children into institutions.

\section{Is International Adoption More Problem Than Solution?}

Many of course say it is. They claim it is plagued with abuses such as babybuying, fraud on birth parents, corruption of government officials, and even kidnapping. Some even claim that international adoptees suffer abuse in their new countries. Some in Russia who supported the recent shutdown of adoption to the U.S. cited claims that 19 Russian adoptees had died in the U.S. since Russia began sending children out in the early 1990s. ${ }^{49}$

But as I have discussed at length elsewhere, there is no evidence that such abuses are systemic rather than occasional. For example, assuming the accuracy of the claims re the 19 Russian adoptee deaths, and assuming these are all cases of parental abuse, this would amount to 19 out of the total of 61,118 adoptions over those years, or an abuse rate of $0.0003 .^{50}$ This is a truly minuscule abuse rate compared to the rates that exist for the unparented children in Russia who are likely to be placed in international adoption. Russian orphanages are notoriously bad, plagued by conditions that characterize the most troubled orphanages in the world, and, of course, even the best orphanages damage children in a systematic way, given the absence of anything resembling one-on-one nurturing care.

The harms caused by any adoption abuses that exist are far outweighed by the harms caused when international adoption is shut down and children are

48 See Bartholet, International Adoption, supra note 11, at 170-73, for discussion of these two treaties. Convention on the Rights of the Child, Nov. 20, 1989, 1577 U.N.T.S. 3; the Hague Convention on the Protection of Children and Co-operation in Respect of Inter-Country Adoption, May 29, 1993, 343 U.N.T.S. 89, reprinted in 32 I.L.M. 1134-46 (1993).

49 CNN Staff, Russia's Putin Signs Anti-U.S. Adoption Bill (June 11, 2013), available at http://edition.cnn.com/2012/12/28/world/europe/russia-us-adoptions/index.html?hpt=hp_tl. 50 Bartholet, Intercountry Adoption, supra note 10 (years 1999-2012); Bartholet, International Adoption, supra note 10, Appendix B (years 1992-1998). 
denied by the tens of thousands the nurturing homes they need. The obvious solution is to do better at enforcing the laws prohibiting these abuses and penalize the perpetrators rather than the children. ${ }^{51}$

Other arguments against international adoption get made, including that sovereign states should be entitled to claim ownership in their children, and that children's best interests will almost always be served by staying in their country of origin given the alleged heritage losses involved in international adoption. I don't think these arguments should be taken seriously, and again I have dealt with them extensively elsewhere. ${ }^{52}$

The only serious argument against international adoption has to do with distributive justice. Some argue that international adoption serves the interests of a relative few as compared to the larger group of birth parents and children in need. They say that international adoption diverts from efforts to address the larger group needs. Some argue that international adoption constitutes a modern form of colonialist exploitation, with rich and powerful countries taking the children that represent "precious resources" for less powerful countries.

But as I have argued elsewhere, there is no evidence that international adoption is inconsistent with larger social justice goals, and every reason to believe that in fact it helps push down the long road to reaching those goals, raising consciousness about the needs of poor people worldwide, and bringing significant new resources into poor countries to serve those needs. ${ }^{53}$ Nor is there any reason to think that countries are actually empowered by holding onto their unparented children. The opposite is self-evidently true, as children who grow up on the streets or in institutions are costly both short-term and long-term. If they survive their childhood, they are at high risk of living lives characterized by poverty, unemployment, substance abuse, crime, and they are at high risk for continuing the cycle of dysfunction into the next generation, abusing and neglecting their own children. A recent Better Care Network report notes:

Countries with a history of institutional care have seen developmental problems emerge as these children grow into young adults and experience difficulty reintegrating into society. Research in Russia has shown that one in three children who leaves residential care becomes homeless, one in five ends up with a criminal record and up to one in 10 commits

51 See generally, e.g. Bartholet, International Adoption: The Human Rights Position, supra note 11, at 96-97; Bartholet \& Smolin, Debate, supra note 37, at 237-38, 246.

52 See, e.g., Bartholet, International Adoption: The Human Rights Position, supra note 11, at 9298; Bartholet, International Adoption: Thoughts on the Human Rights Issues, supra note 10, at 177-91; Bartholet \& Smolin, Debate, supra note 38.

53 See generally, e.g. Bartholet, International Adoption: The Human Rights Issues, supra note 11, at 96; Bartholet-Smolin, Debate, supra note 37, at 247. 
suicide. A meta-analysis of 75 studies (more than 3,800 children in 19 countries) found that children reared in orphanages had, on average, an IQ 20 points lower than their peers in foster care. ${ }^{54}$

Russia's own reporting [indicates that] 95 percent of Russian children who grow up in their orphanages end up on the streets, unable to function, and are very likely to die shortly after their 18th birthdays. ${ }^{55}$

Colonialist exploitation can be rightly condemned. But providing parents to children in need really is different from stealing oil and diamonds. Shutting down international adoption may be characterized as resistance to colonialist exploitation, but it is nothing more than a symbolic act of defiance. It does nothing to strengthen the poor country, nothing to make up for the history of exploitation. Instead it helps perpetuate that country's victimization, all at the cost of children's lives.

\section{Intergenerational Injustice in Action: Recent Illustrations of the Problem}

\section{International Adoption Shutdowns}

During the decades leading up to 2004, when international adoption numbers reached their peak, many countries in Latin and South America sent significant numbers of children out to international adoption. Russia, China, India, and various other countries in Asia and Eastern Europe also opened up to international adoption and began to place significant numbers of unparented children abroad. In recent years, international adoption has been cut back severely in these areas. Lately Africa has opened up to international adoption, with growing numbers of children placed. But now there is a call to shut down Africa. ${ }^{56}$ Below I describe briefly developments in countries in each of these areas of the world

54 Williamson \& Greenberg, supra note 16, at 6.

55 Whitney Reitz, Adoption: For Children Without Parents, the Best Form of Protection, LXXIX, No. 5 Vital Speeches May 2013. Whitney Reitz serves as Sr. Policy Advisor on International Child Welfare, office of Senator Mary Landrieu, U.S. Senate, and gave this speech at the Pepperdine Conference, supra note 5 .

56 For trends in international adoption see Peter Selman, The Rise and Fall of Intercountry Adoption in the 21st Century: Global Trends from 2001 to 2010, in InTERCOUNTRY ADOPTION, supra note 21, at 7. See also supra pp. IIB3. 
which help illustrate the dynamics of international adoption shutdowns and their destructive impact on children.

\section{Guatemala}

Guatemala is a country characterized by poverty and limited access to contraception, and for related reasons, high rates of child abandonment. For a period of time international adoption served the needs of at least many of Guatemala's unparented children. As of 2007, Guatemala had the highest numbers of children placed abroad per country population of any country in the world. ${ }^{57}$ But then UNICEF, together with the U.S. and other receiving countries, focused on alleged abuses in the Guatemalan international adoption program and shut it down. In the context of getting Guatemala to ratify the Hague Convention, these forces promoted "reform" legislation which eliminates private intermediaries and promises to severely limit the number of children placed in international adoption in future years. ${ }^{58}$

There is little evidence that since the shutdown there has been any significant expansion of in-country adoption or other programs designed to serve unparented children's needs. Even critics of international adoption admit that there has been limited progress in increasing the small numbers of domestic adoptions - the total finalized in 2009 was only 172. ${ }^{59}$ Despite some alleged progress in improving the domestic child welfare system, the UN Committee for the Rights of the Child reported in 2010 its concerns over the ongoing problem of institutionalization, citing "the high number of children in institutions, as well as ... the insufficient implementation of minimum care standards and monitoring systems ... the placement of more than 1,000 children in a big institution in the capital." 60

While many unite in condemning the Guatemalan system of the past as corrupt, there is little evidence of serious wrongdoing. Some number of birth parents apparently received financial payments in connection with their surrender of children for adoption. There is no reason to believe that many of them were induced to surrender by the payments - most of them would surely have been forced to surrender regardless by their poverty and related inability to

57 Selman, supra note 56, at 16.

58 Kelley Bunkers \& Victor Groza, Intercountry Adoption and Child Welfare in Guatemala, in InTERCOUnTRy Adoption, supra note 21, at 119, 121.

59 Id. at 125.

$60 \mathrm{Id}$. at 126. 
parent. The costs for children of shutting down international adoption include the denial of homes to children who could have received them. At its peak, this was close to 5,000 annually placed in the U.S. alone, and of course with facilitative regulation this number could have been significantly increased. And Guatemala's system was in many ways model from the child's viewpoint, placing children early in life before they had to suffer the damage caused by institutional life.

\section{Romania}

Romania was one of many Eastern European countries that opened up institutional adoption after the fall of communism. Prior to this, during the Ceausescu regime, extreme pronatalist policies were in force. His Decree 770, issued in 1966, banned all family planning including contraception and abortion in order to increase the number of births. Women were rewarded for having children, and childless couples were taxed. This resulted in the highest maternal mortality rate in Europe and in the abandonment of thousands of children to state institutions. By 1989 there were more than 150,000 children in institutions with thousands dying yearly. ${ }^{61}$

With the death of Ceausescu in 1990, the horrors of these institutions were revealed to the world, leading many thousands from the U.S. and other foreign countries to adopt children both out of these institutions and from birth parents unable to care for their children. In 1 year from the summer of 1990 to the summer of 1991, more than 10,000 Romanian children were adopted internationally. ${ }^{62}$ Thousands more were adopted over succeeding years.

International adoption was shut down by "human rights" advocates advising the European Parliament. They insisted that as a condition of being allowed to join the European Union, Romania close its international adoption program. Legislation banning such adoption by anyone other than grandparents was enacted in 2003, and Romania has been closed since. ${ }^{63}$

The result has been to deny homes to many thousands of children in need. The theory was that Romania would develop a better system for taking care of children in-country, reforming child welfare, ending the institutionalization of infants, and increasing domestic adoption. But limited progress has been made.

61 Victor Groza et al., The Adoptive Family Within the Romanian Cultural Context: An Exploratory Study, 15 Adoption Q. 1, 1-2 (2012).

62 Id.

$63 I d$. at 2. 
What has been termed "the Romanian shell game" has resulted in the babies who were no longer supposed to be placed in institutions, simply being left in hospitals for extended periods of time. While there has been a decrease in the overall number of children in institutions, there has been almost as large an increase in the number of children in foster care. Domestic adoption exists but only in small numbers with little progress in increasing those numbers. ${ }^{64}$ So, for example, domestic adoptions grew from 1,291 in 2000 to 1,300 in 2008, and the rate, calculated as number of adoptions per number of children in out-of-home care, from 0.023 to $0.029 .{ }^{65}$

\section{Africa}

This and the next generation are in desperate straits in most African countries due to AIDS, war, poverty, limited contraception, and high reproduction rates. UNICEF estimates there are now some 58 million orphans on the continent. ${ }^{66}$ Progress in providing the many millions of unparented children with families has been limited. While there is a new emphasis on the importance of emptying orphanages, overall there has been little progress toward this goal. Moreover, the in-country placement options being promoted are primarily paid foster care, group homes, and sibling-headed households, options that are not likely to serve children nearly as well as international adoption. In-country adoption is relatively rare and, given most African countries' bias against adoption, together with their poverty and other problematic conditions, will not likely become common any time soon. ${ }^{67}$

One bright spot for unparented children in recent years has been the increasing number of children placed in international adoption. Africa has been the fastest growing international adoption area in the world during this period of general retrenchment in other areas. ${ }^{68}$

However, this growth has, as elsewhere, now triggered a demand for shutdown. In May 2012, African leaders from over 20 countries convened in Addis Ababa, Ethiopia at the recent African Child Policy Forum (ACPF) conference on

64 Id. at 3-5; Christina Nedelcu \& Victor Groza, Child Welfare in Romania: Contexts and Processes, in Intercountry Adoption, supra note 21, at 91.

65 Nedelcu \& Groza, supra note 64, at 97-98.

66 UNICEF, The State of the World's Children 2012, available at http://www.unicef.org/publications/index_61789.html.

67 See supra note 39, and see also discussion at IIA1 supra.

68 See Selman, supra note 56, at 11, 21-24. 
"Intercountry Adoption: Alternatives and Controversies." They called for limiting international adoption to at best, last resort status. ${ }^{69}$ This conference was designed to address the growing placement of African children in international adoption - placement seen by those in charge as representing a "crisis in child rights."70 The claim was that such adoption violated child human rights, under the African Charter on the Rights and Welfare of the Child, as well as the Convention on the Rights of the Child. ${ }^{71}$ Such adoption was condemned as having "facilitated trafficking for prostitution, sex slavery rings, live organ harvesting and hard labour." 72 There is, of course, no evidence that international adoption facilitates these things. Prior to the conference the executive director of the ACPF, David Mugawe, said in a press statement: “[International adoption] must at all costs be discouraged. It should be a last resort and an exception rather than the normal recourse to solving the situation of children in difficult circumstances .... Every child should have an inalienable right to be nurtured and reared in the country and culture in which they are born."73 The ACPF issued a Report on the eve of the conference calling for rejection of international adoption except as a "very last resort," taking place only in exceptional circumstances. $^{74}$

\section{International Surrogacy Expansion}

Simultaneous with the cutback in international adoption has been a dramatic increase in international commercial surrogacy. Such surrogacy typically involves privileged adults from nations going to poor or relatively poor women in relatively poor countries, and offering them money to get pregnant and to

69 Elizabeth Willmott-Harrop, Adoption Trade Sets up Shop in Africa: Pan African Conference Addresses Emerging Crisis in Child Rights, available at http://libertyandhumanity.com/freelancewriting/Adoption-trade-sets-up-shop-in-Africa.

70 See Willmott-Harrop, id.

71 African Charter on the Rights and Welfare of the Child, OAU Doc. CAB/LEG/24.9/49 (1990), entered into force Nov. 29, 1999; Convention on the Rights of the Child, Nov. 20, 1989, 1577 U.N.T.S. 3.

72 Willmott-Harrop, supra note 69, at 2, quoting First Lady of Uganda.

73 Whiteman, CNN, African Adoption Should be Discouraged "At All Costs," Group Says - CNN. com, available at http://edition.cnn.com/2012/05/29/world/africa/africa-child-adoption/.

74 Intercountry Adoption: Alternatives and Controversies, The Fifth International Policy Conference on the African Child, Conference Report, the African Child Policy Forum (ACPF) (2012), Preface. See also Intercountry Adoption: Alternatives and Controversies, Proceedings of The Fifth International Policy Conference on the African Child, Conference Report, the African Child Policy Forum (ACPF) (2012). 
surrender the child at birth, transferring parental rights to those who paid for the arrangement. The birth mother, called the surrogate, sometimes contributes her egg, and sometimes gets pregnant using IVF embryos created from another woman's egg, sometimes, but not always, the egg of the woman who hopes to be the rearing mother. The sperm are generally provided either by the intending social father or by a third party sperm vendor. The child is born with the design that it will be raised not by its birthing parent and not in the country in which it is born, but by parents in another country. These social parents may or may not have any genetic connection to the child.

International surrogacy raises many of the problems critics complain about in the context of international adoption. Thus adoption is criticized for involving abuses like baby-buying, for the exploitation involved in taking children from their birth families and transferring them to privileged others, for denying children their heritage rights, for bringing money into poor countries that corrupts and distorts the system so that it fails to serve the interests of the poor people within the country.

Surrogacy involves all these problems and more. ${ }^{75}$ Surrogacy is by its nature baby-buying, in contrast to adoption which universal law forbids any payment to the birth parents that might induce surrender. While this adoption law is sometimes violated, there is no evidence that it is systematically violated. Surrogacy systematically involves payments to birth mothers, with the payments clearly designed to induce the surrender of babies and of parenting rights. Full payment of the fee to the surrogate occurs only after the surrender of parental rights. Surrogacy involves children losing their birth heritage and sometimes their genetic heritage. Where the surrogate is made pregnant through the IVF process as is increasingly the case, it involves all the health risks that go with IVF for both mother and child. It also involves loss of national heritage assuming, as critics of international adoption do, that being born on one side of a national border gives a baby a national heritage birthright. Surrogacy, like other medical tourism, brings significant funds into the countries that serve as providers. Experts on medical tourism have raised concerns as to whether this financial pressure is a corrupting influence, leading to less adequate medical and other care for local citizens. ${ }^{76}$

75 See generally Cohen, supra note 24, at 1374-86, cataloguing the ethical concerns as including child welfare, anticommodificationist corruption, and exploitation; Biggs \& Jones, supra note 23, at 164, 171-77 (discussing child welfare, exploitation and health concerns).

76 Deonandan, supra note 25, at 166 ("[T]he responsiveness of the destination state to the needs of its citizenry may be co-oped by the needs of the industry. While the influence of big business on government policy is not unusual, it is nonetheless regrettable when the rights and needs of poor and vulnerable women are in play."); Storrow, supra note 24, at 125, 126 
Most significant, surrogacy imposes these problems and losses deliberately, creating children designed to be sold and to be cast off by their birth and often their genetic parents for others to raise. Adoption by contrast, gives existing children something hugely important, parenting, and if they suffer losses these are necessary losses, more than made up for by the gain represented by the opportunity to be parented.

Among the countries that have allowed and embraced international commercial surrogacy are several that have shut down or severely restricted international adoption - Guatemala, Russia, and India. ${ }^{77}$ India is particularly popular because of facilitative legislation enforcing surrogacy contracts and thus giving commissioning parents a better guarantee of what they want - the chance to parent the child of surrogacy. ${ }^{78}$ Some 25,000 couples a year now travel to India for surrogacy. ${ }^{79}$ Some estimate that the surrogacy industry in India is worth between $\$ 500$ million and $\$ 2.3$ billion. ${ }^{80}$ The practice will apparently soon extend to Nepal, a country that recently shut down international adoption. $^{81}$

It is highly likely that international commercial surrogacy will continue to expand just as other forms of medical tourism will. ${ }^{82}$ The huge amounts of money already involved will motivate this expansion. Also, many celebrate the kind of globalization they see represented in medical tourism. The Introduction to a recent book on medical tourism concludes:

As borders become more porous to people, services and ideas, what we see is an evolving concept of both the global citizen and the medical service provider; such a concept is formed in a context wherein neither trade nor medical relief are restricted by geography or

(discussing concerns that "cross-border reproductive care" or CBRC may have negative impact on equitable delivery of health care in destination countries); Labonte, supra note 26, at 9, 31-32, 34 (health care of those in destination countries may be compromised by emphasis on the more lucrative foreign market).

77 See Bartholet, International Adoption: The Human Rights Position, supra note 11, at 97. See generally Cohen, supra note 24, at 1323-24 (discussing thriving medical tourism trade including surrogacy, and major destination countries).

78 Cohen, supra note 24, at 1324.

79 Our Bodies Ourselves, Winter 2012-2013 Newsletter, 1, 5, available at http://www.ourbodiesourselves.org/uploads/pdf/winter2013news.pdf (discussing surrogacy in India and Nepal). See also Deonandan, supra note 25, at 153 (India one of world's greatest providers of surrogacy, raising issues involving exploitation of women, welfare of children produced, and others related to absence of protective regulation).

80 Deonandan, supra note 25, at 153.

81 Our Bodies Ourselves, supra note 79.

82 See discussion, supra text at nn. 26-27. 
domestic values, legalities and mores, but rather by whatever international frameworks the global community seeks to define and apply. ${ }^{83}$ [sic.]

By contrast, international adoption policy-makers cling to a romanticized preglobalization world, one in which nation states are all-important, children belong where they came from, and children must be denied needed homes if those homes exist across a national border.

Cutting back on international adoption, while expanding international surrogacy, makes no sense for existing children in need of homes. And assuming there are problems with severing birth, genetic and national ties, it makes no sense for future children - since there is a limited number of children who will be born it makes more sense to encourage the production of children who are not deliberately designed to suffer losses. ${ }^{84}$ This pattern makes sense only for adults. It involves millions of dollars for those facilitating the arrangements and for the governments sponsoring them. It gives the commissioning parents what they want, newborns to parent.

\section{Conclusions}

Restructuring policy to better serve intergenerational justice would be a huge task, involving many different ambitious projects. We would need to address the world poverty and chaos that mean so many birth parents give birth to children they cannot raise. We would need to create child welfare systems that work to support families and enable parents to nurture children. We would need to change the economic and regulatory structure that shapes parenting choices between caring for existing children and creating new children. ${ }^{85}$

One part should be easy. We could stop getting in the way of the parents who are ready to volunteer, even in the absence of systematic reform, to parent existing children in need. International adoption is a truly extraordinary social reform program in that it is essentially paid for by the private actors motivated to parent, requiring no diversion of resources by governments in poor countries.

83 Deonandan et al., Introduction, in Travelling Well, supra note 25, at 1, 4.

84 While no social science exists demonstrating such harms, none exists either demonstrating that harms come to adopted children brought up by non-biologically linked parents, and yet extensive social policy exists prioritizing the importance of keeping children with their birth parents if at all possible. See FAmily Bonds, supra note 22, at 164-86.

85 For an interesting attempt to address some of the individual and social moral issues inherent in changing this structure, see S. J. Chapman, supra note 20, at 24-33. 
Indeed, it saves such governments significant resources by removing children who otherwise would have to be supported and who would grow up to become a major cost to society. It brings significant new resources into poor countries through the range of adoption fees paid, through the in-country charitable programs often created by international adoption agencies to help the children who cannot be adopted, and through ongoing contributions by grateful adoptive parents whose consciences have been aroused by exposure to the conditions in their children's countries of origin. ${ }^{86}$ Most significant, international adoption magically transforms the lives of most of those children placed, providing what for most is the only opportunity they will have to gain what all children need, parenting. Given how hard it is to accomplish significant social reform, it would be a crime not to embrace this particular reform.

Note: The author has written extensively on adoption and reproduction issues and relies on her prior work throughout. See generally http://www.law.harvard.edu/faculty/bartholet/pubs.php.

86 See Bartholet, International Adoption, supra note 10, at 179-85; Bartholet, International Adoption: The Human Rights Position, supra note 11, at 94-96. 